\title{
Editor's Message: US Environmental Protection Agency's Coal Combustion Residuals Rule strengthens regulatory recognition of karst groundwater flow
}

\author{
Chris Groves ${ }^{1}$ \\ Received: 28 June 2017 / Accepted: 11 September 2017 / Published online: 4 October 2017 \\ (C) Springer-Verlag GmbH Germany 2017
}

Keywords Karst · Groundwater monitoring · Carbonate rocks $\cdot$ Contamination $\cdot$ Groundwater protection $\cdot$ CCR rule

Karst landscapes and aquifers form in especially soluble bedrock, most often in carbonate rocks such as limestone, and are characterized by features such as caves, sinkholes, underground rivers, and large springs. Porosity elements range from small pore spaces to conduits that are often meters or even tens of meters in diameter. While most storage is in small openings that have been hardly modified (Palmer 2007), most karst groundwater typically moves as turbulent flow through the largest conduits. High heterogeneity and anisotropy create challenges for groundwater monitoring and numerical modeling.

Some of the techniques typically employed for investigating groundwater in porous media systems are not readily applicable for the study and monitoring of karst groundwater flow and so methods have been developed specifically for karst aquifers (e.g. Quinlan and Ewers 1986; Quinlan 1989, Goldscheider and Drew 2007; Groves 2007) including fluorescent dye tracing, mapping of underground rivers through direct exploration or geophysics, and high-resolution monitoring of integrative springs. These methods are now well established and used in karst terrains, often combined with traditional techniques; however, an ongoing problem is that some groundwater monitoring regulations are not consistent

C. Groves is an associate editor of Hydrogeology Journal

Chris Groves

chris.groves@wku.edu

1 Crawford Hydrology Laboratory, Western Kentucky University, Bowling Green, KY 42101, USA with the concept that the majority of groundwater flow in karst aquifers tends to be through discrete conduits (e.g. Quinlan and Ewers 1986; Palmer 2007; Ewers 2016). This includes the fact that wells - a mainstay for groundwater monitoring in porous media aquifers - can often be ineffective for successfully monitoring karst groundwater (Fig. 1). Quinlan and Ewers (1986) wrote that the "probability of a randomly located monitoring well intercepting the trunk conduit which drains a groundwater basin, or the tributary conduit which drains a site, is similar to the probability of a dart thrown at a wall map of the United States hitting the Mississippi River or

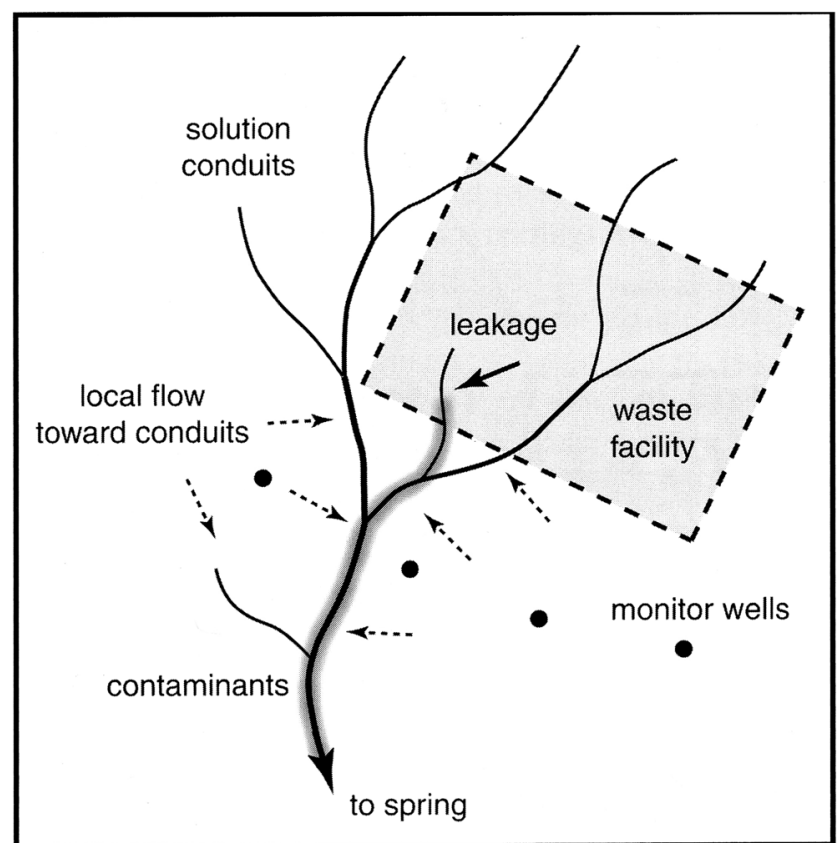

Fig. 1 Diagram showing how conduits within a well-developed karst aquifer may pass between even closely spaced monitoring wells. Note that the hydraulic gradient (shown by dotted arrows) is towards the conduits throughout the aquifer (Palmer 2007) 
a specific tributary." Because local hydraulic gradients and groundwater flow in the vicinity of active stream conduits will tend to be towards those conduits (see arrows in Fig. 1), wells that are not direct hits into the principal conduits may be unlikely to intersect contaminated groundwater draining from a contamination source. The technology for appropriate monitoring of karst groundwater flow systems has advanced greatly and recommendations for effective monitoring of karst systems, with their basic layout still intact, were established decades ago (e.g. Schindel et al. 1988; Quinlan 1989; EPA 1992).

Quinlan and Ewers (1986) wrote that the US Environmental Protection Agency (EPA):

"should officially recognize that the problems of ground water in maturely karsted carbonate terranes are different from those in granular aquifers. A different monitoring strategy is required...EPA should encourage, sanction and require the use of dye-traces, springs and wells drilled to known cave streams - rather than conventionally located wells - for the design of monitoring systems in most carbonate terranes."

Recently, Ewers (2016) described the current situation:

"In spite of their manifest shortcomings in carbonate aquifers, monitoring wells are specified by law in virtually every case where contaminants may be or have been released. Unfortunately, these wells are usually placed using criteria appropriate for granular aquifers. Alternative and more appropriate means of aquifer assessment and monitoring in these aquifers are available, including wells augmented with tracer investigations and the use of springs and other access points to the conduit elements of the porosity system."

One of the EPA's principal regulatory strategies for the protection of groundwater resources is the Resource Conservation and Recovery Act (RCRA). RCRA details methods to minimize the potential for the migration of hazardous materials into groundwater by limiting the placement of hazardous materials into the environment, utilizing liners or leachate collection systems, and remediating solid waste units (SWMU; EPA 2004). A critical component of this strategy involves groundwater monitoring in the potentially impacted zones associated with SWMU, and the basic template for this requires a minimum of "four wells, one upgradient from the unit and three downgradient" from the source. Upgradient wells are intended to sample background concentrations of the relevant constituents presumably unaffected by the contaminant source and downgradient wells are intended to show if there is a difference from the waters of the first wells to show whether the source has indeed been responsible for the water quality degradation. Downgradient wells represent points of compliance, where concentrations are established to determine whether contaminants are migrating from the regulated unit. While this design would typically be effective in porous media or finely fractured aquifers where contaminants tend to spread out in blob-like plumes (Fig. 2), flow in the discrete conduits of well-developed karst aquifers can pass undetected by even closely spaced wells (Fig. 1). This problem, that such well placement requirements may not detect releases in welldeveloped karst aquifers, has been known to the EPA-in 1992, in a draft technical guidance document, the intrinsic problems with the use of monitoring wells in karst terrains were described and it was concluded (EPA 1992, pp. 5-13) that:

"It may be possible for some facilities that are sited above conduit flow aquifers to have ground-water monitoring systems that meet the performance standards of 40 CFR §264.97. The Regional Administrator may require the facility owner or operator to monitor seeps, springs, and caves that are hydraulically connected to the uppermost aquifer and that are within the facility boundary to supplement the monitoring well network. These supplemental monitoring sites can be used in conjunction with point of compliance wells to detect releases from the facility $(\$ 264.97(a)(3))$. However, the Agency expects that these cases will be rare, and that most facilities sited in karst settings will be unable both to meet the performance standards of $\$ 264.97$ and to receive an operating permit."

In the meantime, however, there are indeed contaminated sites in karst settings being monitored, at least in some cases, with sampling strategies more appropriate to porous media (e.g. Ewers 2016). Throughout the United States, karst landscape/aquifer systems cover only about $18 \%$ of the land surface area (Weary and Doctor 2014); however, large portions of some states such as Tennessee, Kentucky and Missouri have these conditions, and karst aquifers in Florida and Texas are critical sources of water supply.

While progress varies by location, overall there has been significant progress in minimizing or eliminating hazardous discharges into karst aquifers. While advancement of the regulation of groundwater monitoring in karst systems has been more incremental, there has also been some progress. Tennessee, for example, is underlain by karst aquifers over much of the central and eastern portions of the state (Wolfe et al. 1997). The presence of karst is recognized (TDEC 2015) and is reflected in relevant solid waste regulations in some settings. Under Permit by Rule guidelines, for example, new coal ash disposal fill areas must not be located "in highly developed karst terrain (i.e. sinkholes and caves)." Similarly, 
Fig. 2 Diagram showing typical well placement for a monitoring program designed to track a contaminant in a porous media aquifer where contaminants often travel in large, blob-like plumes that are relatively easy to hit with monitoring wells (modified from New Jersey Department of Environmental Protection 2012)

\section{Generalized Monitoring Well Network}

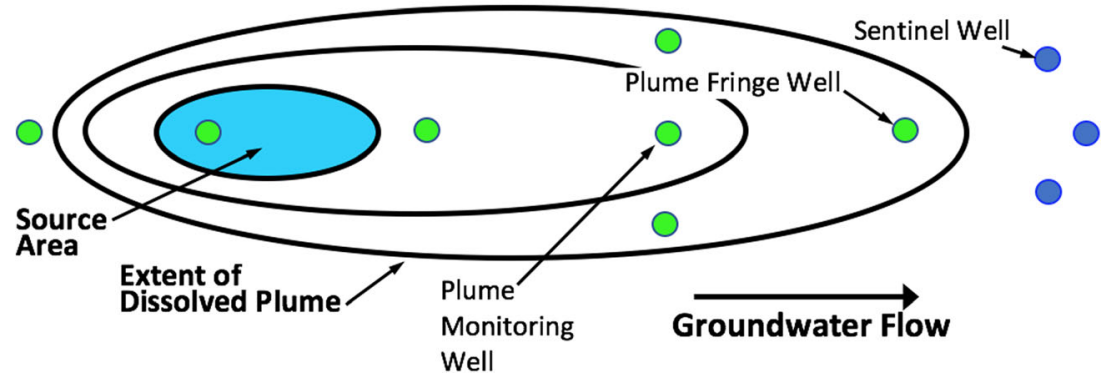

for new solid waste disposal units of any type that are "proposed in a highly developed karst terrain," an applicant must demonstrate that "location in the karst terrain will not cause any significant degradation to the local groundwater resources."

Enforcing these laws, however, requires monitoring. The same section of the Tennessee regulations indicates that any demonstration that required conditions have been met may (but not must) "require the installation of piezometers, the developing of a potentiometric surface map of ground water, conducting geophysical surveys, dye tracing or other specific requirements." New and existing facilities must have a groundwater monitoring system with a sufficient number of upgradient and downgradient monitoring locations and, in karst flow systems, these may include not just wells, but also springs. Kentucky, which has karst landscapes over some $50 \%$ of its area (Currens 2002), also allows the use of springs as monitoring locations (Kentucky Legislature 2016).

For any particular site, the monitoring strategy and engineering/institutional controls implemented depend on the experience and judgment of the project or site manager assigned to the particular program. These decisions are constrained by both the flexibility of the regulations and the availability of administrative personnel with adequate understanding of karst hydrogeology. Implementing the best possible science is also of course influenced by the legal framework that gives the authority for the work and defines the procedural steps required for increasingly sophisticated, which in some cases means karst-appropriate, methods to be justified.

Recent federal EPA language has recognized the peculiarities of karst groundwater flow in the US with the finalization of the EPA's Disposal of Coal Combustion Residuals from Electric Utilities Rule (CCR Rule, 40 CRF 257.50, Disposal of Coal Combustion Residuals from Electric Utilities Rule; US EPA 2015). CCR refers to the residual products of coal burning and these represent one of the largest sources of solid waste generated in the US. The CCR can generate leachate that can contain mercury, arsenic, selenium and other constituents (Swaine 2013). The rule "establishes nationally applicable minimum criteria for the safe disposal of coal combustion residuals in landfills and surface impoundments" and includes provisions requiring establishment of groundwater monitoring networks. With regard to karst, the CCR Rule's preamble (Disposal of Coal Combustion Residuals from Electric Utilities Rule; US EPA 2015) says that in fulfilling the requirements for performance standards for groundwater monitoring systems specified in the rule's section 257.91, that:

"In making a demonstration, it is important for owners and operators of CCR landfills and surface impoundments in karst areas to adequately characterize subsurface conditions. Therefore, the owner or operator will need to ensure, with verification by a qualified professional engineer, that monitoring wells installed in accordance with $\S 257.91$ will intercept these pathways. Verification will usually necessitate the use of tracers to track groundwater flow towards offsite seeps or springs from the uppermost aquifer beneath the facility."

With respect to existing regulations that mandate monitoring well configurations designed to intersect broad contaminant plumes (Fig. 2), this strategy implemented correctly would indeed increase the ability to identify contaminated groundwater impacted by a solid waste disposal facility in a karst setting (Fig. 1).

Karst groundwater tracing, which most commonly utilizes fluorescent dyes and is arguably the most important technique of karst hydrogeology, is very useful in determining where the contaminated water will go, and from what spring it will ultimately emerge. In many cases, identifying the impacted spring rather than the conduit(s) between the source and the spring can be an effective, and easier, way to identify critical monitoring points. As invoked in the language, however, verification that an important underground stream has been intersected would best involve tracing from the leaking waste unit, either using introduced dye or quite possibly the contaminant itself (or themselves as the case may be) as the tracer. Isotopically distinct boron, for example, can be useful as a tracer for CCR leachate (Ruhl et al. 2014).

Aside from the potential to completely miss contamination pathways in karst systems using porous media sampling techniques, another factor that can impact sampling results is that 
flow and chemical conditions can change very rapidly in conduit flow settings - for example, contaminants may be flushed through during storm events and have very different concentrations than the concentrations present during drier conditions. Karst spring hydrochemistry is typically weather dependent, and sampling programs should consider characterization of the system and constituent(s) of interest-for example, in some cases light or dense non-aqueous phase liquids (DNAPLs or LNAPLs) may be observed only during storm events, and other constituents might only be detected on sediment when mobilized. These types of temporal variations are in general not the case in porous media aquifers, and therefore traditional investigation techniques would often not be effective for sites in karst media.

While identifying and sampling the conduits can be an effective way to sample contamination in a karst aquifer-a great improvement over "one upgradient and three downgradient" wells - in practice it is typically difficult and very expensive. In many cases, springs make effective, cheaper to implement, and much easier monitoring points. This highlights, however, what may be a fundamental disconnect in how monitoring regulations can be implemented in karst flow systems. While springs often make the most effective monitoring sites (Fig. 1), the basic regulatory basis for groundwater monitoring programs is to identify releases of contamination before they have migrated beyond a compliance boundary for the regulated facility. By the time a spring is contaminated, it may well be too late for that.

Another consideration for the CCR Rule language is that although many engineers have training in geology or geotechnical skills, the siting and logging of monitoring wells is more a task of geology than of engineering. Future regulations that require the identification of features in wells as described in the CCR Rule might well consider requiring a registered professional geologist to perform this and other geological functions described in the rule.

What is the situation from an international perspective? There is no clearinghouse for information to answer this complex question, but communication from more than 20 years of extensive international interactions of karst scientists through various programs, including those of the of the International Association of Hydrogeologists (IAH) and the UNESCO/ IUGS International Geoscience Program (Groves et al. 2012), can allow some reasonable observations. Karst landscapes cover some $12.5 \%$ of the world's ice-free land area (Ford and Williams 2007; Hollingsworth 2009) and have been estimated to provide water to as much as $25 \%$ of the world's population (Ford and Williams 2007). Politically this includes parts of at least 202 countries (Hollingsworth 2009) so there is a tremendous range of policy with regard to environmental protection and specifically for monitoring of groundwater. Environmental agencies within many countries simply have little technical infrastructure with regard to an understanding of karst water resources and, even within countries with important karst water resources, these agencies may have only one or perhaps a handful of karst groundwater experts, or in some cases maybe none. The common situation seems to be that even in countries where there has been increased awareness and understanding of karst hydrogeology, technically appropriate regulations, if they exist at all, have not kept pace. The situation is much better in some areas, such as European countries where population pressures have put high demand on karst aquifers (Koreimann et al. 1996) and where dye tracing and other methods appropriate to karst hydrology are well developed (e.g. Goldscheider and Drew 2007). Information thus gained has been used in collaboration with regional groundwater monitoring programs and groundwater vulnerability mapping strategies (e.g Zwahlen 2003) to establish source water protection programs to help protect karst groundwater resources, although there is still work necessary to establish and perhaps explore ways to standardize the most effective mapping strategies.

In the US, carbonate rocks cover about one fifth of the land area, and the karst groundwater systems that form within them are widespread, provide critical water resources, and are highly vulnerable to contamination. While much progress has been made in understanding the behavior of karst aquifers and the details of individual flow systems, and appropriate methods to study and evaluate them, development of appropriate legal frameworks for the monitoring of karst groundwater has moved more slowly. Although in 1992 the EPA wrote (EPA 1992, pp. 5-13) that "most facilities sited in karst settings will be unable both to meet the performance standards of $\$ 264.97$ and to receive an operating permit", karst sites continue to be used. With the recent and explicit regulatory recognition of the importance of conduit flow in the effective monitoring of karst aquifers, the EPA's CCR Rule may help to reduce an existing gap between regulation and field constraints.

Karst groundwater is very easily contaminated, and karst aquifers behave differently from porous media systems. Simply avoiding development on karst landscape/aquifer systems is not an option, and so effort must be made to continue to develop a more sophisticated understanding of how to effectively utilize and protect them and the resources they provide. This includes continued evolution of an effective body of regulation that recognizes things as they are, and effectively takes into account the peculiarities of karst systems.

Acknowledgements I appreciate the efforts of the following colleagues who made thoughtful and helpful suggestions based on earlier versions of this article, although the opinions expressed in it are solely my own: Cayla Baughn, Rob Blair, Lee Anne Bledsoe, Deven Carigan, Cesalea Osborne, Geary Schindel, James H. Smith, and staff of the EPA's Office of Resource Conservation and Recovery/OSWER. Discussions with Mark Quarles have been especially helpful. 


\section{References}

Currens JC (2002) Kentucky is Karst country! What you should know about sinkholes and springs. Kentucky Geol Surv Inform Circ 4 Ser XII

EPA (1992) RCRA ground-water monitoring: draft technical guidance. US Environmental Protection Agency, Washington, DC

EPA (2004) Handbook of groundwater protection and cleanup policies for RCRA corrective action for facilities subject to corrective action under Subtitle $\mathrm{C}$ of the Resource Conservation and Recovery Act. EPA530-R-04-030, US Environmental Protection Agency, Washington, DC

EPA (2015) Disposal of Coal Combustion Residuals from Electric Utilities Rule. 80 Fed. Reg. 21151-21638 (April 15, 2015). US Environmental Protection Agency, Washington, DC

Ewers R (2016) On the efficacy of monitoring wells in karstic carbonate aquifers, chap 10. In: Caves and karst across time. Geol Soc Spec Pap 516

Ford DC, Williams PW (2007) Karst hydrology and geomorphology. Wiley, Chichester, UK

Goldscheider N, Drew D (eds) (2007) Methods in karst hydrogeology. Taylor and Francis, New York

Groves C (2007) Hydrologic techniques. In: Goldscheider N, Drew D (eds) Methods in karst hydrogeology. Taylor and Francis, New York, pp 45-64

Groves C, Zhang C, Yuan D (2012) IGCP 299, 379, 448, 513, and 598: global efforts to understand the nature of karst systems - over two decades with the IGCP. In: Derbyshire E (ed) Tales set in stone: 40 years of the International Geoscience Programme. UNESCO, Paris, pp 80-87

Hollingsworth E (2009) Karst regions of the world: populating global karst datasets and generating maps to advance the understanding of karst occurrence and protection of karst species and habitats worldwide. MS Thesis, University of Arkansas, Fayetteville, AK

Kentucky Legislature (2016) Kentucky Administrative Regulations Title 405. http://www.lrc.ky.gov/kar/TITLE405.HTM. Accessed 27 May 2016

Koreimann C, Grath J, Winkler G, Nagy W, Vogel WR (1996) Groundwater monitoring in Europe. European Environment Agency, Copenhagen
New Jersey Department of Environmental Protection (2012) Ground water technical guidance: site investigation remedial investigation remedial action performance monitoring. April 3, 2012. New Jersey Department of Environmental Protection, Trenton, NJ

Palmer AN (2007) Cave geology. Cave Books, Dayton, OH

Quinlan JF (1989) Ground-water monitoring in Karst terranes recommended protocols and implicit assumptions. EPA/600/X-89/050, US Environmental Protection Agency, Washington, DC

Quinlan JF, Ewers RO (1986) Reliable monitoring in karst terranes: it can be done, but not by an EPA-approved method. Ground Water Monit Remediat 7(1):4-6. https://doi.org/10.1111/j.1745-6592.1986. $\operatorname{td} 01221 . x$

Ruhl LS, Dwyer GS, Hsu-Kim H, Hower JC, Vengosh A (2014) Boron and strontium isotopic characterization of coal combustion residuals: validation of new environmental tracers. Environ Sci Technol 48(24):14790-14798. https://doi.org/10.1021/es503746v

Schindel GM, Trimble D, Spalding T (1988) A ground water protection strategy for Karst Terranes. Proceedings of the 2nd Conference on Environmental Problems in Karst Terranes and their Solutions, National Water Well Association, Westerville, $\mathrm{OH}$

Swaine DJ (2013) Trace elements in coal. Butterworth-Heinemann, London

TDEC (2015) Rules of the Tennessee Department of Environment and Conservation Solid Waste Management Chapter 0400-11-01 Solid Waste Processing and Disposal 2015 (revised). http://share.tn.gov/ sos/rules/0400/0400-11/0400-11-01.20150527.pdf. Accessed 28 May 2016

Weary DJ, Doctor DH (2014) Karst in the United States: a digital map compilation and database. US Geol Surv Open File Rep 2014-1156

Wolfe WJ, Haugh CJ, Webbers A, Diehl TH (1997) Preliminary conceptual models of the occurrence, fate, and transport of chlorinated solvents in karst regions of Tennessee. US Geol Surv Water Resour Invest Rep 97-4097

Zwahlen F (2003) Vulnerability and risk mapping for the protection of carbonate (karst) aquifers scope-goals-results. Final report of the European Commission Cost Action 620, Directorate-General Science Research and Development, EC, Brussels 